\title{
Wolf-Sightings on the Canadian Arctic Islands
}

\author{
FRANK L. MILLER ${ }^{1}$ and FRANCES D. REINTJES ${ }^{1}$
}

(Received 6 April 1994; accepted in revised form 13 March 1995)

\begin{abstract}
A wolf-sighting questionnaire was sent to 201 arctic field researchers from many disciplines to solicit information on observations of wolves (Canis lupus spp.) made by field parties on Canadian Arctic Islands. Useable responses were obtained for 24 of the 25 years between 1967 and 1991. Respondents reported 373 observations, involving 1203 wolf-sightings. Of these, 688 wolves in 234 observations were judged to be different individuals; the remaining 515 wolf-sightings in 139 observations were believed to be repeated observations of 167 of those 688 wolves. The reported wolf-sightings were obtained from 1953 field-weeks spent on 18 of 36 Arctic Islands reported on: no wolves were seen on the other 18 islands during an additional 186 field-weeks. Airborne observers made $24 \%$ of all wolf-sightings, 266 wolves in 48 packs and 28 single wolves. Respondents reported seeing 572 different wolves in 118 separate packs and 116 single wolves. Pack sizes averaged $4.8 \pm 0.28$ SE and ranged from 2 to 15 wolves. Sixty-three wolf pups were seen in 16 packs, with a mean of $3.9 \pm 2.24 \mathrm{SD}$ and a range of $1-10$ pups per pack. Most $(81 \%)$ of the different wolves were seen on the Queen Elizabeth Islands. Respondents annually averaged 10.9 observations of wolves $\bullet 100$ field-weeks ${ }^{-1}$ and saw on average 32.2 wolves $\bullet 100$ field-weeks ${ }^{-1} \cdot \mathrm{yr}^{-1}$ between 1967 and 1991 . Average rates of wolf observations $\cdot 100$ field-weeks ${ }^{-1}(28.5,13.6$ vs. $5.7 ; p<0.005)$ and mean numbers of different wolves seen 100 field-weeks ${ }^{-1}$ $(92.3,37.5$ vs. $15.4 ; p<0.005)$ were markedly greater during $1967-75$ and 1989-91 than in 1976-88. Relative differences in the reported rates of wolf observations on the Queen Elizabeth Islands in 1967-75, 1976-88, and 1989-91 follow the relative abundance of the wolf's major prey, Peary caribou (Rangifer tarandus pearyi) and muskoxen (Ovibos moschatus), on those islands during those periods.
\end{abstract}

Key words: arctic-island wolves, Canis lupus spp., Canadian Arctic Islands, wolf-sighting questionnaire, reported wolf observations

RÉSUMÉ. Un questionnaire portant sur l'observation de loups a été envoyé à 201 chercheurs de divers domaines travaillant dans l'Arctique, dans le but de solliciter de l'information sur la présence de loups (Canis lupus sp. plur.) notée par des groupes sur le terrain dans l'archipel Arctique canadien. Des réponses utilisables ont été obtenues pour 24 des 25 années allant de 1967 à 1991. Les répondants ont rapporté 373 cas d'observations au cours desquels ils ont vu 1203 loups. De ces derniers, 688 loups ont été jugés être des individus distincts, comptés lors de 234 cas d'observations; parmi les autres 515 loups aperçus au cours des 139 autres cas d'observations se retrouvaient sans doute 167 des 688 loups mentionnés ci-dessus. Les observations de loups rapportées ont été faites durant 1953 semaines de travail sur le terrain passées sur 18 des 36 îles de l'archipel Arctique sur lesquelles portait la recherche; aucun loup n'a été vu sur les autres 18 îles au cours de 186 semaines de travail supplémentaires sur le terrain. Vingtquatre p. cent des cas d'observations de loups ont été faits par des observateurs aéroportés, qui ont noté 226 loups en 48 bandes et 28 loups solitaires. Les répondants ont dit avoir vu 572 loups différents répartis en 118 bandes distinctes et 116 loups solitaires. La taille des bandes était en moyenne de 4,8 \pm 0,28 ES et allait de 2 à 15 loups. Soixante-trois louveteaux ont été aperçus dans 16 bandes ayant de 1 à 10 louveteaux par bande et une moyenne de 3,9 2,24 EMQ louveteaux par bande. La plupart (81 p. cent) des loups différents ont été aperçus sur les îles de la Reine-Élisabeth. Les répondants ont vu des loups en moyenne 10,9 fois par an 100 semaines sur le terrain ${ }^{-1}$ et ont compté en moyenne 32,2 loups 100 semaines sur le terrain ${ }^{-1} \cdot$ an $^{-1}$ entre 1967 et 1991 . La fréquence moyenne d'observations de loups-100 semaines sur le terrain ${ }^{-1}(28,5,13,6$ c. 5,$7 ; p<0,005)$ et le nombre moyen de loups différents aperçus. 100 semaines sur le terrain ${ }^{-1}(92,3,37,5$ c. 15,4; $p<0,005)$ étaient nettement plus élevés au cours des années 1967 à 1975 et 1989 à 1991 qu' au cours des années 1976 à 1988. Les différences relatives entre les fréquences d'observations de loups rapportées sur les îles de la Reine-Élisabeth en 1967-1975, 1976-1988 et 1989-1991 s'accordent avec l'abondance relative des proies principales du loup, le caribou de Peary (Rangifer tarandus pearyi) et le boeuf musqué (Ovibos moschatus), sur ces îles au cours de ces périodes.

Mots clés: loups de l'archipel Arctique, Canis lupus sp. plur., archipel Arctique canadien, questionnaire portant sur les cas d'observations de loups, observations de loups rapportées

Traduit pour la revue Arctic par Nésida Loyer.

\footnotetext{
${ }^{1}$ Canadian Wildlife Service, Northern Conservation Division, Environmental Conservation Branch, Prairie \& Northern Region, Environment Canada, Room 200, 4999 - 98 Avenue, Edmonton, Alberta T6B 2X3, Canada

(C) The Arctic Institute of North America
} 


\section{INTRODUCTION}

Wolves (Canis lupus spp.) on the Canadian Arctic Archipelago (CAA) are highly visible on the open tundra to ground observers and to relatively low-level airborne observers, when the wolves are moving. Visibility is greatest when the wolves are on a snow-free background, which generally corresponds to the period of maximal human activity on the CAA, late June to August. Adult wolves on the Arctic Islands usually are white or generally white or whitish in appearance. They are curious and most are relatively bold compared to other subspecies of C. lupus, and often behave like shy dogs in the presence of humans (e.g., Grace, 1976; Miller, 1978; Munthe and Hutchinson, 1978). Arctic-island wolves tend to investigate everything that is new to them, including field camps or field party members that they encounter in their environment. Thus, if wolves are present in the area of a field camp, they are likely to be seen.

Essentially all of the ca. 11500 year-round residents on the CAA (Northwest Territories Data Book 1990/91, 1990) live in widely scattered, small, coastal Inuit settlements. Even though Inuit hunters and trappers on occasion travel over large areas of the Arctic Islands (e.g., Riewe, 1992), vast tracts of land remain isolated and remote, except for infrequent visits or overflights by scientific or exploration field parties. Therefore, most arctic-island wolves apparently lack experience with humans, especially those wolves on the Queen Elizabeth Islands.

There is little information on the biology, ecology, population dynamics or current status of wolves on the CAA. A recent evaluation has been made, however, of the probable status of wolves on the Arctic Islands by examining the "theoretical maximum carrying capacities" for wolves in various areas of the archipelago in relation to their available ungulate prey base (Miller, 1993). The ungulate prey base is composed solely of caribou (Rangifer tarandus spp.) and muskoxen (Ovibos moschatus). Wolves are large, attractive carnivores that are of interest to people and usually of strong interest to arctic field researchers, regardless of their discipline. Therefore, in the absence of essentially any systematic and quantitative data on past, recent, or current numbers of wolves on the CAA, we produced a "wolf-sighting" questionnaire to solicit observations of wolves made by field parties on the CAA. Herein, we report our analyses of the data obtained from the wolf-sighting questionnaire.

\section{STUDY AREA}

The CAA forms the northern apex of North America and encompasses a landmass of more than 1.3 million $\mathrm{km}^{2}$. It represents one-seventh of the land area of Canada and spans nearly $60^{\circ}$ of longitude $\left(66-126^{\circ} \mathrm{W}\right)$ and $22^{\circ}$ of latitude $(61-$ $\left.83^{\circ} \mathrm{N}\right)$. The tundra vegetation of the Canadian Arctic Islands consists of lichens, bryophytes, graminoids, herbs, cushion plants, and prostrate shrubs with some low, erect shrubs occurring on protected sites in southern and eastern parts of the archipelago (Babb and Bliss, 1974; Edlund and Alt, 1989; Bliss, 1990; Edlund, 1990). For the purpose of reporting our findings, we have divided the CAA into three regions and ten major areas generally reflective of climate and patterns of vegetation cover (cf. Miller, 1993) (Figs. 1 to 3). The "Queen Elizabeth Islands region" (QEI) is divided into five major areas: (1) eastern islands, (2) southwestern islands, (3) southcentral islands, (4) north-central islands, and (5) northwestern islands. The "Southern Tier of Arctic Islands region" (STI) includes three major areas: (1) western islands, (2) eastern islands, and (3) south-central islands. The "Baffin Island region" (BIR) is divided into (1) northern and (2) southern areas.

\section{MATERIALS AND METHODS}

Three subspecies of the North American gray wolf have been identified on the CAA: (1) C. l. arctos, Pocock (1935), originally referred to as the "American tundra wolf" by Pocock (1935) but subsequently called the Canadian polar wolf by Anderson (1946); (2) C. l. manningi, Anderson (1943), the Baffin Island tundra wolf; and (3) C. l. bernardi, Anderson (1943), the Banks Island tundra wolf. C. l. arctos occurs throughout the QEI (those islands north of the Parry Channel or north of $74^{\circ} \mathrm{N}$ latitude, excluding the BIR) and most likely throughout the southern tier of islands (those islands south of the Parry Channel or south of ca. $74^{\circ} \mathrm{N}$ latitude), except Baffin and its satellite islands (Miller, 1993). Pelage descriptions of the three arctic-island subspecies have been made by Pocock (1935), Anderson (1943), Manning (1943), Manning and Macpherson $(1958,1961)$ and Clark (1971). There is likely intergradation of $C$. $l$. arctos with mainland subspecies such as $C$. l. hudsonicus and $C$. $l$. mackenzii on the STI and, at least sporadically, between $C$. $l$. arctos on Ellesmere Island and C. l. orion from Greenland or on Greenland (e.g., Manning and Macpherson, 1961; Dawes et al., 1986). C. l. manningi is known only from Baffin Island; but most recently, R.M. Nowak, (Staff Specialist, Office of Endangered Species, U.S. Fish and Wildlife Service, pers. comm. 1992) has suggested that C. l. manningi should probably be lumped into a major North American group-C. $l$. nubilus - along with the mainland races of C. l. hudsonicus and C. l griseoalbus. C. l. bernardi is known only from its type locality in the Cape Kellett area of Banks Island. It appears to have gone extinct sometime between 1918 and 1952 , or the specimens examined were merely immigrants from the mainland and did not represent a valid subspecies (cf. Manning and Macpherson, 1958).

In 1990, we mailed a wolf-sighting questionnaire to 201 arctic field researchers soliciting the following information: (1) year of observation, (2) month(s) of observation, (3) week(s) spent in the field, (4) island where sighting(s) was made, (5) wolf pack size (given by $1+$ yr old wolves plus pups), (6) number of solitary individual wolves seen, (7) number of times the same wolf or wolves were seen, (8) whether the observer(s) was airborne or on the ground, and (9) the name of the observer. We received 99 (49\%) responses 


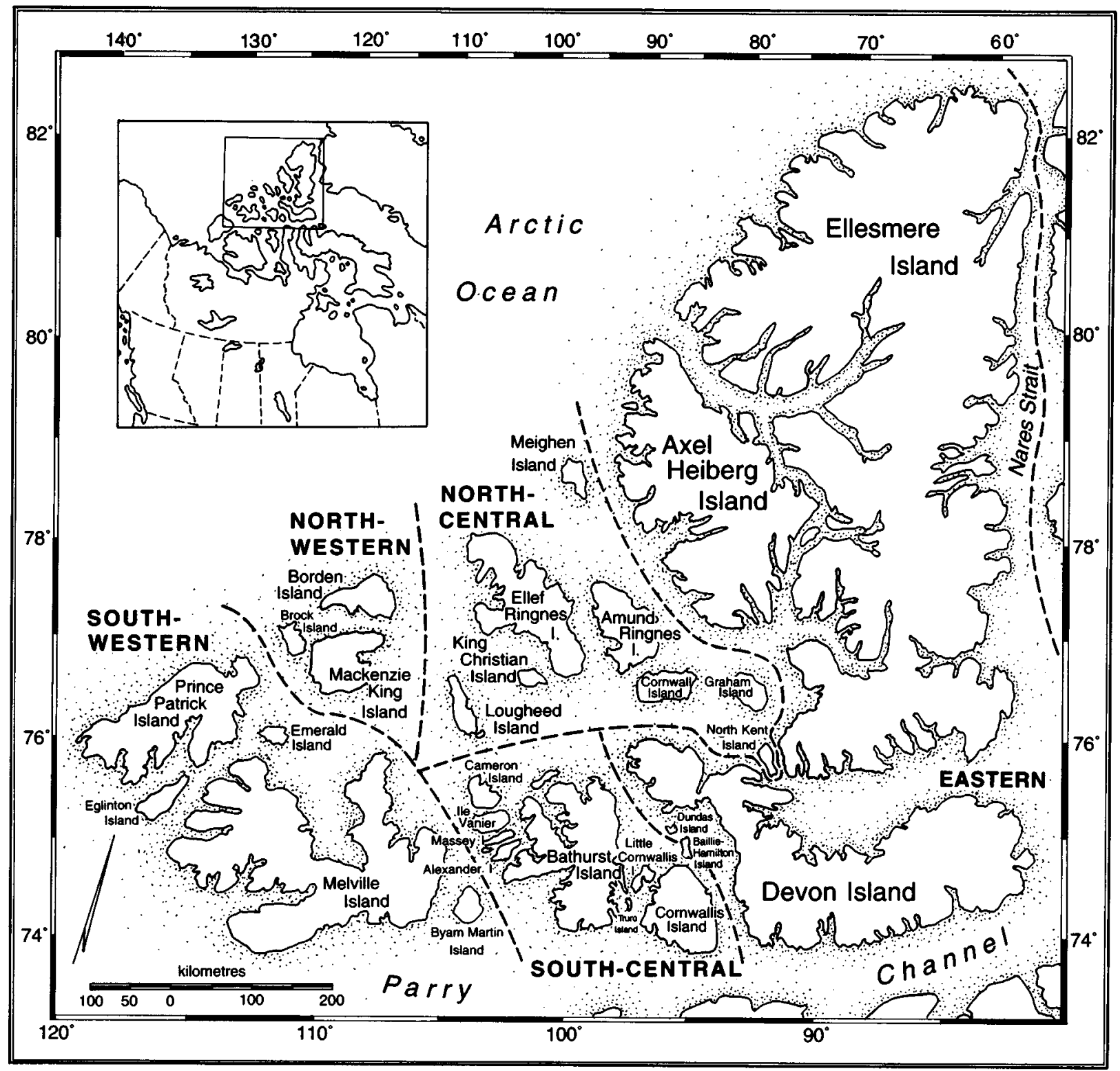

FIG. 1. Queen Elizabeth Islands region (QEI) divided into five major areas by apparent importance to arctic-island wolves.

to the 201 questionnaires but data from only 78 of those respondents were usable. The other 21 respondents simply informed us that they had no data on the subject (for a wide variety of reasons), or they reported only for areas other than the CAA. Subsequently, we received completed wolf-sighting questionnaires from an additional eight field researchers for the 1991 season only.

It was not practical to expect field researchers to provide the degree of detail most desirable for a highly accurate measure of "search effort" or the "rate of wolf-sightings" (i.e., number of person-hours in the field under conditions that likely would have been associated with a high probability of making a wolf-sighting). Therefore, we opted for a general measure of "observer effort," which we termed a "fieldweek," to approximate the effort involved in obtaining wolfsightings (single wolves or wolf packs). We define a "fieldweek" as one week of field activity by one or more persons in a field party, with no actual measure of the number of people involved, the proportion of time spent in camp vs. out of camp, the type of work being carried out, or the proportion of time spent airborne vs. working on the ground. We recognize that there are unmeasured (and possibly unknown) factors that would or could have influenced the accuracy of this measure of observer effort based on our field-week unit. It is, however, the most feasible unit that we could obtain to help reflect the "commonness of wolf sightings over time" from people's recollections and records of field activities on the Arctic Islands over the past four decades.

Respondents to our wolf-sighting questionnaire reported on 545 field periods (2206 field-weeks) on 36 Canadian Arctic Islands: 14 major islands $\left(>10000 \mathrm{~km}^{2}\right), 10$ intermediate-sized islands $\left(>1000\right.$ to $\left.<10000 \mathrm{~km}^{2}\right)$, and 12 small islands $\left(<1000 \mathrm{~km}^{2}\right)$. Their responses included information on field periods during 31 of the 41 years between 1950 and 




FIG. 2. Southern Tier of Arctic Islands region (STI) divided into three major areas by apparent importance to arctic-island wolves.

1991, with no information given for 1952, 1954-60, 1964, and 1969. The first sighting of a wolf was not reported, however, until 1967. We define a "wolf-sighting" as the sighting of one wolf on one occasion. For example, one wolf seen five times equals five wolf-sightings, five wolves seen once also equals five wolf-sightings, five wolves seen three times equals 15 wolf-sightings, and so on.

Wolves were not seen by the five respondents (14 field periods) who collectively spent 67 field-weeks from June to September during seven years between 1950 and 1966 on seven different islands. These were Cornwallis Island (26 field-weeks), 1950 (7), 1951 (8), 1953 (7), and 1961 (4); Victoria Island (15 field-weeks), 1963 (3), 1965 (4), and 1966 (8); Devon Island (12 field-weeks), 1965; Banks Island (6 field-weeks), 1965; Bathurst Island (3 field-weeks), 1961; Bylot Island (3 field-weeks), 1963; and southern Baffin Island (2 field-weeks), 1965 (1), and 1966 (1). The information for 1950 to 1966 is both spatially and temporally fragmentary and, based on 1967-91 sighting rates and the relatively few weeks spent on each island between 1950 and 1966, no more than two wolf-sightings would have been expected from any of those islands. Therefore, we have omitted those five responses for the years prior to 1967 from further consideration.

We have treated repeat observations of wolves separately, as it is likely that with time the making of subsequent repeat wolf-sightings (multiple sightings of the same wolves) usually will be markedly greater than making the first observation of those wolves. This condition pertains because "resighting curves" generally decline with time for initial sightings of new individuals (or packs). For example, once arctic-island wolves have located a field camp, they are likely to return to it out of curiosity, as it represents a novel stimulus in their environment. Such visits are likely to be frequent, particularly if the wolves experience no harmful events while 


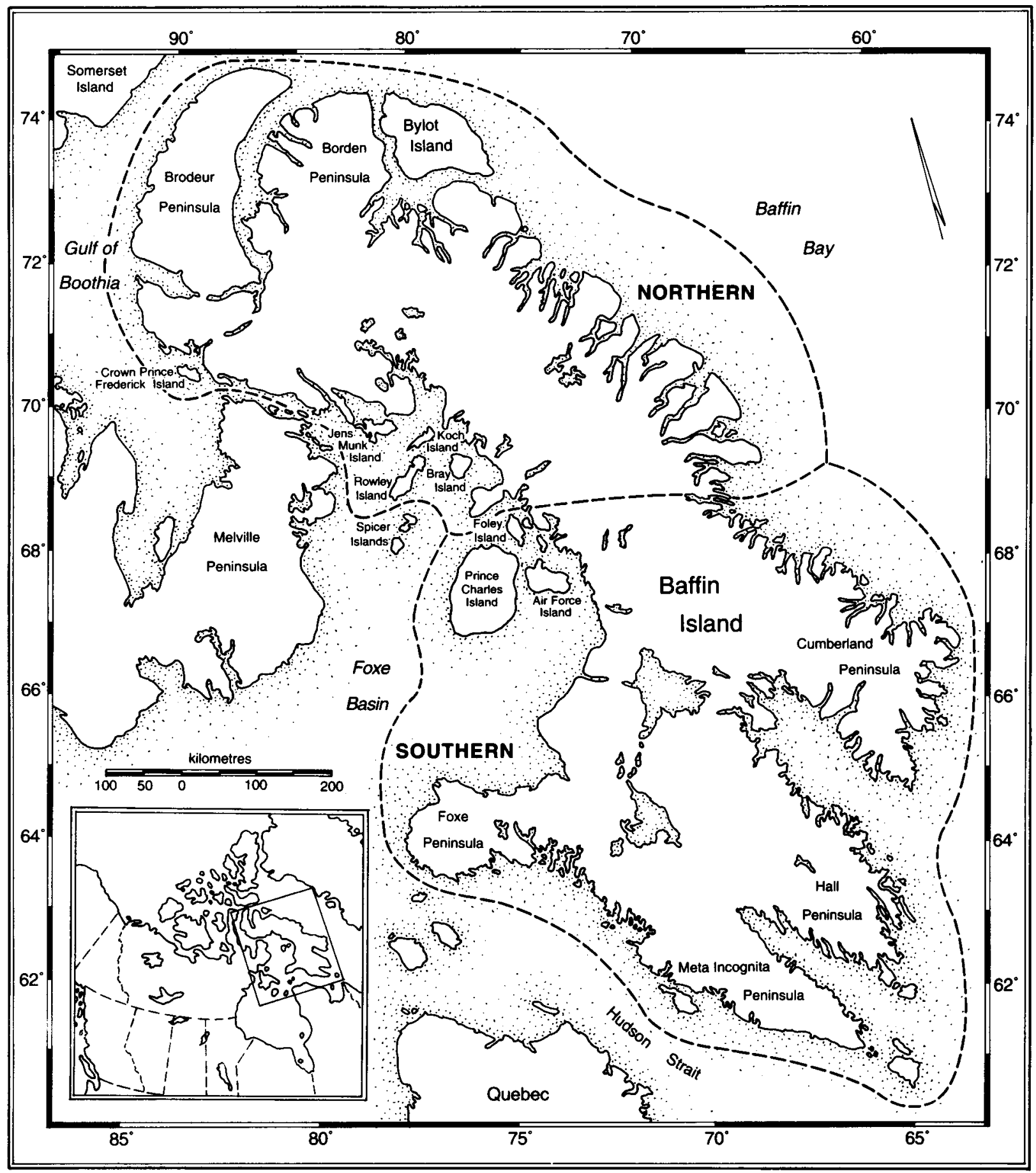

FIG. 3. Baffin Island region (BIR) divided into two major areas by apparent importance to arctic-island wolves.

visiting (that is, if the field party does not discourage the wolf visits). Also, the field work being carried out may take members of the field party back to sites or areas where wolves were previously seen. Knowledge of the probable presence of wolves will often make field workers more alert to the possibility of seeing a wolf or wolves, which should increase the probability of doing so. Therefore, any resultant rate of wolf observations, wolf-sightings, or any measure of observer effort will most probably be markedly inflated by the relative contribution of repeat sightings of the same wolves to the contribution made by the first-time sightings of different wolves only. The following results are based on the information obtained from 81 respondents, who provided records for 531 field periods, involving 2139 field-weeks on 36 Arctic Islands within the CAA for 24 of the 25 years (no data in 1969) from the first wolf-sighting in 1967 through summer 1991.

\section{RESULTS AND DISCUSSION}

Respondents reported 373 observations, involving 1203 wolf-sightings of which 688 wolves in 234 observations were 
judged to be different individuals and the remaining 515 wolf-sightings in 139 observations were repeated observations of 167 of those 688 wolves (Tables $1-3$, Figs. $1-6$ ). The reported wolf-sightings were obtained from 1953 field-weeks spent on 18 Arctic Islands. In actuality, respondents made all of their wolf-sightings during 655 of those 1953 field-weeks and they saw no wolves during the remaining 1298 fieldweeks that they spent on those 18 islands. Therefore, on islands where wolves were seen, respondents spent on average 8.3 field-weeks to make one observation of wolves (involving different wolves only) or 5.2 field-weeks for an observation that sometimes included repeat observations of some of the same wolves. Those observations averaged 35.2 different wolves $\bullet 100$ field-weeks ${ }^{-1}$ or 61.6 wolf-sightings $\bullet 100$ field-weeks ${ }^{-1}$ of field activities. No wolves were seen during 186 field-weeks of collective field activities on the northern half of Baffin Island (55 field-weeks) and 18 other islands: Bylot, 57 field-weeks; Dundas, 30; Rowley, 16; King William, 5; Griffith, 4; Baillie-Hamilton, 3; Ellef Ringnes, 3; Jenny Lind, 2; Prince Charles, 2; and one field-week each on Airforce, Bray, Brock, Cornwall, Crown Prince Frederick, Foley, Meighen, Russell, and Truro. On the basis of the mean rate of sighting of one wolf per three field-weeks, 5-19 wolfsightings should have been made on Rowley, Dundas, northern Baffin, and Bylot islands. Thus, the total lack of wolfsightings on those islands suggests that wolves were absent or rare. The time spent on each island was too short to determine relative density of wolves on any of the other 15 islands where no wolves were seen.

Over four-fifths of all the observations $(n=234)$ of different wolves seen in packs or as single wolves were made by respondents on the QEI (Table 1). The largest number of wolves seen was on southwestern QEI. No wolves were reported for the northwestern QEI, the south-central islands of the STI, or the northern area of the BIR.

Airborne observers made 20\% (76) of all observations, and only $3 \%$ of those observations involved repeat sightings (three repeats of the same pack of 10 wolves during a single field period). Those 76 observations provided $24 \%$ (294) of all of the wolf-sightings. They included 266 sightings of wolves in 48 packs ( $22 \%$ of all wolf-sightings; $33 \%$ of all 146 packs, mean pack size $5.5 \pm 0.49 \mathrm{SE}$, range of pack sizes $2-15)$ and 28 sightings of single wolves. The 73 first-time observations made from the air ( $31 \%$ of all observations of different wolves) contributed 38\% (264) of all of the different wolves seen, including 236 wolves in 45 separate packs ( $41 \%$ of all different wolves seen in packs, $38 \%$ of all 118 different packs seen, mean pack size $5.2 \pm 0.49 \mathrm{SE}$, range of pack sizes $2-15$ ); and $24 \%$ (28) of all single wolves seen.

Proportional representation of observations of wolves in packs vs. observations of single wolves varied significantly between airborne and ground observers $\left(\chi^{2}=5.3, \mathrm{df}=1 ; p\right.$ $<0.05)$. Compared to the number of separate packs (73) and single wolves (88) reported by ground observers, the number of observations made by airborne observers of wolves in separate packs (45) was overrepresented and the number of observations of single wolves (28) underrepresented. This condition, seemingly, suggests that single wolves are more difficult to detect from the air than are packs of two or more wolves. Although it seems evident that the detection of several wolves should be easier than detecting just one, it is also possible that once one wolf is seen, the observer is alerted to the possible presence of other wolves and is more likely to detect others, if present, after the first wolf is seen.

\section{Wolf Packs}

Wolf packs were observed on 16 islands. Respondents reported seeing 572 different wolves in 118 separate packs (Table 1; Fig. 4: overall mean pack size $4.8 \pm 0.28 \mathrm{SE}$, range of pack sizes $2-15$ ). Excluding the 30 pairs of wolves, the resultant 88 packs averaged 5.8 $\pm 0.31 \mathrm{SE}$ in size and ranged from 3 to 15 animals. The greatest number of packs was seen on the QEI, $82 \%$ of all packs, with $80 \%$ of all different wolves seen in packs, and $67 \%$ of all the different wolves that were reported. Within the QEI, 89\% of the packs were equally distributed between the eastern and southwestern areas. Observations from the STI contributed $15 \%$ of all the packs, with $18 \%$ of all the wolves seen in packs, and $15 \%$ of all the different wolves reported. Those packs were nearly equally distributed between the western (56\%) and the eastern (44\%) areas of the STI. Only three different packs (3\%), with three wolves each, were seen in the BIR (on southern Baffin Island in three different years).

There was no significant difference in the mean size of packs within the eastern (mean $4.2 \pm 0.34 \mathrm{SE}$ ), southwestern (5.4 \pm 0.54$)$, and south-central ( $4.3 \pm 0.87)$ areas of the QEI;

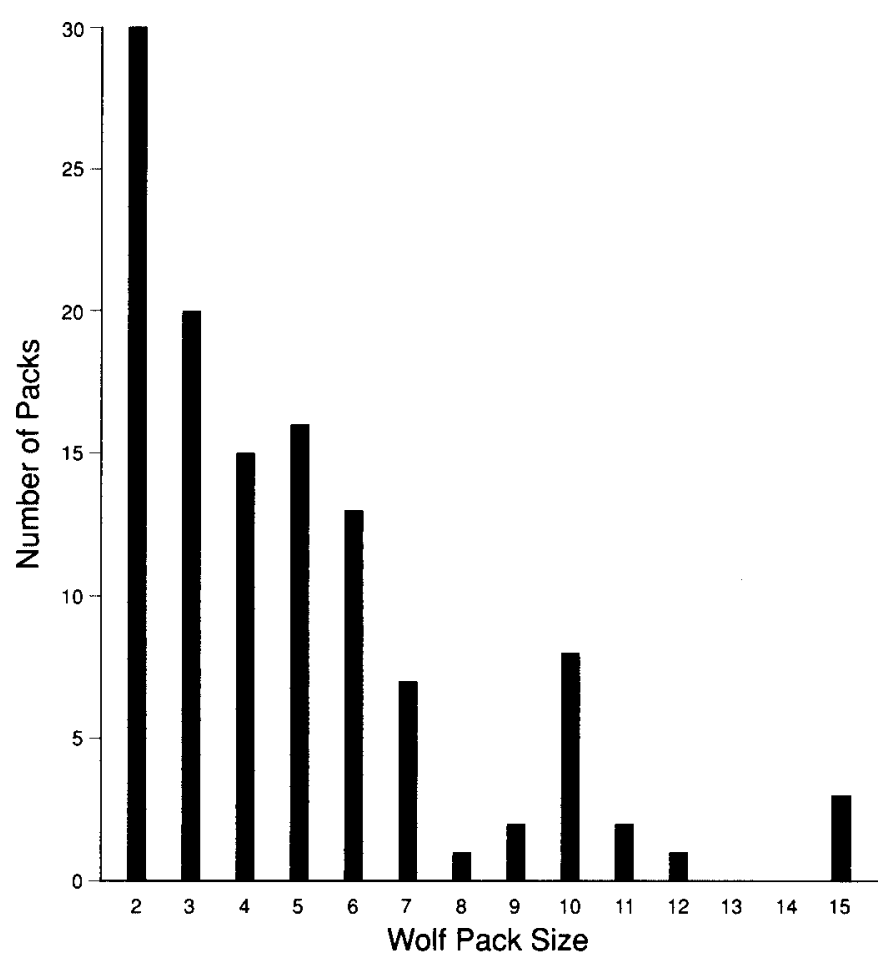

FIG. 4. Distribution of wolves seen in packs during initial observations, as indicated by the frequency of packs of different size, Canadian Arctic Archipelago, 1967-91. 
TABLE 1. Distribution of "observer effort" ( $\mathrm{n}=1953$ field-weeks) and wolf-sightings of 688 different wolves by region, area, and island, Canadian Arctic Archipelago, 1967-91.

\begin{tabular}{|c|c|c|c|c|c|c|c|c|c|c|}
\hline \multirow{2}{*}{$\begin{array}{l}\text { Region/area } \\
\text { Island }\end{array}$} & \multicolumn{2}{|c|}{$\begin{array}{c}\text { Effort } \\
\text { number of field-weeks } \\
\text { when wolves were }\end{array}$} & \multirow{2}{*}{$\begin{array}{c}\text { Number of } \\
\text { different } \\
\text { wolves } \\
\text { seen }\end{array}$} & \multicolumn{3}{|c|}{ Packs seen } & \multirow{2}{*}{$\begin{array}{c}\text { Number of } \\
\text { singletons } \\
\text { seen }\end{array}$} & \multirow{2}{*}{$\begin{array}{l}\text { Number } \\
\text { of pups } \\
\text { seen }\end{array}$} & \multirow{2}{*}{$\begin{array}{c}\text { Time } \\
\text { span } \\
\text { involved }\end{array}$} & \multirow{2}{*}{$\begin{array}{c}\text { Number of } \\
\text { years when } \\
\text { wolves } \\
\text { were seen }\end{array}$} \\
\hline & Seen & Not seen & & $\mathrm{n}$ & Mean \pm SE & Range & & & & \\
\hline \multicolumn{11}{|c|}{ Queen Elizabeth Islands region } \\
\hline $\begin{array}{l}\text { Eastern area: } \\
\text { Ellesmere } \\
\text { Devon } \\
\text { Axel Heiberg }\end{array}$ & $\begin{array}{r}196 \\
27 \\
30\end{array}$ & $\begin{array}{r}198 \\
237 \\
67\end{array}$ & $\begin{array}{r}197 \\
8 \\
30\end{array}$ & $\begin{array}{r}34 \\
2 \\
7\end{array}$ & $\begin{array}{l}4.4 \pm 0.41 \\
3.5 \pm 2.12 \\
3.3 \pm 0.61\end{array}$ & $\begin{array}{l}2-11 \\
2-5 \\
2-6\end{array}$ & $\begin{array}{r}47 \\
1 \\
7\end{array}$ & $\begin{array}{r}15 \\
0 \\
0\end{array}$ & $\begin{array}{l}1967-91 \\
1967-88 \\
1981-90\end{array}$ & $\begin{array}{r}19 \\
3 \\
6\end{array}$ \\
\hline $\begin{array}{l}\text { Southwestern area: } \\
\text { Melville } \\
\text { Prince Patrick } \\
\text { Eglinton } \\
\text { Byam Martin }\end{array}$ & $\begin{array}{l}84 \\
67 \\
12 \\
16\end{array}$ & $\begin{array}{r}24 \\
12 \\
0 \\
0\end{array}$ & $\begin{array}{r}181 \\
70 \\
13 \\
3\end{array}$ & $\begin{array}{r}27 \\
12 \\
3 \\
1\end{array}$ & $\begin{array}{l}5.8 \pm 0.71 \\
5.2 \pm 0.82 \\
4.0 \pm 1.00 \\
2.0 \pm 0.00\end{array}$ & $\begin{array}{l}2-15 \\
2-10 \\
2-6 \\
2-2\end{array}$ & $\begin{array}{r}24 \\
8 \\
1 \\
1\end{array}$ & $\begin{array}{r}14 \\
9 \\
1 \\
0\end{array}$ & $\begin{array}{l}1971-88 \\
1973-89 \\
1973-74 \\
1973-74\end{array}$ & $\begin{array}{r}10 \\
6 \\
2 \\
2\end{array}$ \\
\hline $\begin{array}{c}\text { South-central area: } \\
\text { Bathurst } \\
\text { Cornwallis } \\
\text { Cameron } \\
\text { Lowther }\end{array}$ & $\begin{array}{r}31 \\
6 \\
3 \\
3\end{array}$ & $\begin{array}{r}38 \\
233 \\
1 \\
1\end{array}$ & $\begin{array}{r}30 \\
8 \\
13 \\
1\end{array}$ & $\begin{array}{l}6 \\
1 \\
3 \\
0\end{array}$ & $\begin{array}{c}4.0 \pm 1.37 \\
6.0 \pm 0.00 \\
4.3 \pm 1.20 \\
-\end{array}$ & $\begin{array}{l}2-10 \\
6-6 \\
2-6 \\
-\end{array}$ & $\begin{array}{l}6 \\
2 \\
0 \\
1\end{array}$ & $\begin{array}{l}0 \\
0 \\
3 \\
0\end{array}$ & $\begin{array}{c}1973-90 \\
1970-89 \\
1988-91 \\
1981\end{array}$ & $\begin{array}{l}7 \\
2 \\
3 \\
1\end{array}$ \\
\hline $\begin{array}{l}\text { North-central area: } \\
\text { Lougheed } \\
\text { King Christian }\end{array}$ & $\begin{array}{l}3 \\
2\end{array}$ & $\begin{array}{l}0 \\
5\end{array}$ & $\begin{array}{l}1 \\
3\end{array}$ & $\begin{array}{l}0 \\
1\end{array}$ & $\begin{array}{c}- \\
3.0 \pm 0.00\end{array}$ & $\begin{array}{l}- \\
3-3\end{array}$ & $\begin{array}{l}1 \\
0\end{array}$ & $\begin{array}{l}0 \\
1\end{array}$ & $\begin{array}{l}1979 \\
1982\end{array}$ & $\begin{array}{l}1 \\
1\end{array}$ \\
\hline \multicolumn{11}{|c|}{ Southern Tier of Arctic Islands region } \\
\hline $\begin{array}{l}\text { Western area: } \\
\text { Victoria } \\
\text { Banks }\end{array}$ & $\begin{array}{r}5 \\
50\end{array}$ & $\begin{array}{r}96 \\
139\end{array}$ & $\begin{array}{l}14 \\
41\end{array}$ & $\begin{array}{l}3 \\
7\end{array}$ & $\begin{array}{l}4.7 \pm 1.20 \\
5.4 \pm 1.29\end{array}$ & $\begin{array}{l}3-7 \\
2-10\end{array}$ & $\begin{array}{l}0 \\
3\end{array}$ & $\begin{array}{r}2 \\
10\end{array}$ & $\begin{array}{l}1987-90 \\
1974-90\end{array}$ & $\begin{array}{l}2 \\
8\end{array}$ \\
\hline $\begin{array}{l}\text { Eastern area: } \\
\text { Prince of Wales } \\
\text { Somerset }\end{array}$ & $\begin{array}{l}57 \\
16\end{array}$ & $\begin{array}{r}24 \\
105\end{array}$ & $\begin{array}{r}52 \\
4\end{array}$ & $\begin{array}{l}7 \\
1\end{array}$ & $\begin{array}{l}7.1 \pm 1.28 \\
2.0 \pm 0.00\end{array}$ & $\begin{array}{l}2-11 \\
2-2\end{array}$ & $\begin{array}{l}2 \\
2\end{array}$ & $\begin{array}{l}8 \\
0\end{array}$ & $\begin{array}{l}1976-89 \\
1988-91\end{array}$ & $\begin{array}{l}6 \\
3\end{array}$ \\
\hline $\begin{array}{c}\text { Baffin Island region } \\
\text { Southern area: } \\
\text { South Baffin }\end{array}$ & 47 & 118 & 19 & 3 & $3.0 \pm 0.00$ & $3-3$ & 10 & 0 & $1967-90$ & 6 \\
\hline
\end{tabular}

${ }^{1}$ Lowther Island was placed in the south-central area of the Queen Elizabeth Islands region although it lies to the south in the waters of Barrow Strait.

and the western $(5.2 \pm 0.94)$, and eastern $(6.5 \pm 1.28)$ areas of the STI. Sample sizes for packs in the north-central area $(n=1)$ of the QEI and the southern area $(n=3)$ of the BIR were too small to evaluate for comparison from area to area. The number of wolves seen in packs on an island was strongly correlated with the number of packs seen (Pearson Correlation, $\mathrm{r}=0.982$; $p=0.001$ ) but not with mean pack size (Pearson Correlation, $\mathrm{r}=0.453 ; p=0.078)$, suggesting that mean pack size was similar among all islands where wolf packs were seen.

\section{Wolf Pups}

Respondents saw 63 pups in 16 packs (Table 1, Fig. 5). Mean pack size was $7.9 \pm 3.14 \mathrm{SD}$; range, $3-15$, with a mean of $3.9 \pm 1.77 \mathrm{SD}$ and a range of $1-7$ for $1+\mathrm{yr}$ olds and a mean of $3.9 \pm 2.24 \mathrm{SD}$ and a range of $1-10$ for pups. The most frequently observed numbers of pups in a pack were four and five (four observations each). Significantly $\left(\chi^{2}=10.56\right.$, df $=1$; $p<0.005)$ fewer $1+$ yr old wolves were present in packs with 5-10 pups than in packs containing only $1-4$ pups (Fig. 5).

Wolf pups were seen in only $14 \%$ of the 118 packs reported. All of the pups were seen between June and
September of the year. Most observers, however, would not necessarily recognize the previous year's pups, when seen during the months from January through May. The proportion of packs with pups present is still only $17 \%$, when the 26 packs (167 wolves, mean pack size $6.4 \pm 3.80 \mathrm{SD}$, range of pack sizes 2-15) seen between January and May are deleted from this consideration. The proportion of packs with pups present can be increased to a maximum of 24\% (16 of 66 packs) by deleting the 30 pairs of wolves included in the pack data and the 22 packs of three or more wolves each seen sometime during January through May of the year.

These data cannot be used directly to measure pup productivity among years, as arctic-island wolf pups are not regular travellers with the packs until essentially the beginning of winter. Arctic-island wolf pups continue to use rendezvous sites within their summer homesite (Clark, 1971; Packard et al., 1992) or recent kill sites as temporary rendezvous sites, when they begin to travel with the pack after leaving the summer homesite (Gray, 1993) during August or even through September of the year. Also, females with pups are wary and may not approach close enough to readily be seen by people working at other activities. We believe, however, that the 
TABLE 2. Distribution of 515 wolf-sightings from repeat observations of 167 of the 688 different wolves by region, area, and island, Canadian Arctic Archipelago, 1967-91.

\begin{tabular}{|c|c|c|c|c|c|c|c|}
\hline \multirow{3}{*}{$\begin{array}{c}\text { Region/area } \\
\text { Island }\end{array}$} & \multirow{3}{*}{$\begin{array}{l}\text { Number of } \\
\text { singletons }\end{array}$} & \multicolumn{2}{|c|}{ Packs } & \multirow{3}{*}{$\begin{array}{c}\text { Number } \\
\text { of repeat } \\
\text { observations }\end{array}$} & \multirow{2}{*}{\multicolumn{2}{|c|}{ Number of repetitions }} & \multirow{3}{*}{$\begin{array}{c}\text { Total } \\
\text { repetitive } \\
\text { wolf-sightings }\end{array}$} \\
\hline & & \multirow[b]{2}{*}{$\mathrm{n}$} & \multirow{2}{*}{$\begin{array}{l}\text { Number } \\
\text { of wolves }\end{array}$} & & & & \\
\hline & & & & & Involving packs & Involving singletons & \\
\hline \multicolumn{8}{|c|}{ Queen Elizabeth Islands region } \\
\hline \multicolumn{8}{|l|}{ Eastern area: } \\
\hline Ellesmere & 17 & 11 & 56 & 60 & 24 & 36 & 180 \\
\hline Axel Heiberg & 3 & 5 & 14 & 16 & 11 & 5 & 33 \\
\hline \multicolumn{8}{|l|}{ Southwestern area: } \\
\hline Melville & 2 & 5 & 24 & 19 & 17 & 2 & 96 \\
\hline Prince Patrick & 2 & 2 & 10 & 19 & 11 & 8 & 63 \\
\hline \multicolumn{8}{|l|}{ South-central area: } \\
\hline Bathurst & 2 & 0 & 0 & 2 & 0 & 2 & 2 \\
\hline \multicolumn{8}{|l|}{ North-central area: } \\
\hline King Christian & 0 & 1 & 3 & 1 & 1 & 0 & 3 \\
\hline \multicolumn{8}{|c|}{ Southern Tier of Arctic Islands region } \\
\hline \multicolumn{8}{|l|}{ Western area: } \\
\hline Victoria & 0 & 1 & 4 & 1 & 1 & 0 & 4 \\
\hline Banks & 2 & 1 & 10 & 11 & 9 & 2 & 92 \\
\hline \multicolumn{8}{|l|}{ Eastern area: } \\
\hline Prince of Wales & 1 & 2 & 16 & 9 & 4 & 5 & 41 \\
\hline \multicolumn{8}{|l|}{ Baffin Island region } \\
\hline \multicolumn{8}{|l|}{ Southern area: } \\
\hline South Baffin & 1 & 0 & 0 & 1 & 0 & 1 & 1 \\
\hline
\end{tabular}

apparent lack of pups in some years is likely real.

Most of the pups seen (43 in 11 observations, $68 \%$ of all pups seen) were on the QEI and the remaining pups (20 in five observations, $32 \%$ of all pups seen) were on the STI (Table 1). No wolf pups were reported for the BIR. The greatest number of pups in a single pack $(n=10)$ occurred on Melville Island.

\section{Single Wolves}

Single wolves were reported for 15 islands, and respondents saw 116 different single wolves (Table 1: 17\% of all 688 wolves seen). Most (85\%) of those single wolves were seen on the QEI, followed by $9 \%$ seen in the BIR, and $6 \%$ on the STI. Single wolves were reported for only four of the five major areas within the QEI. The largest number of single wolves on the QEI was seen on eastern islands (47\% of all singletons), followed by those on southwestern islands (29\%), south-central islands ( $8 \%$ ), and a north-central island (ca. $1 \%$ ). All 10 of the single wolves seen in the BIR were in the southern area. Most of the single wolves within the STI were seen on eastern islands (ca. 3\%), followed by the three remaining singletons (ca. $2 \%$ ) on a western island, and no singletons were seen on any of the south-central islands.

The number of single wolves seen on an island basis was directly related to the number of wolf packs seen (Pearson Correlation, $\mathrm{r}=0.942 ; p=0.001)$ and the total number of wolves present in packs (Pearson Correlation, $r=0.876$; $p=0.001)$. There was no relationship, however, between mean pack sizes and the number of single wolves seen on an island basis (Pearson Correlation, $\mathrm{r}=0.145 ; p=0.592$ ). Thus, the existing evidence supports the possibility that many or most of the single wolves seen were simply temporarily absent "pack wolves" on solitary foraging trips.

\section{Repeat Observations}

Respondents made 139 repeat observations of wolves (Table 2: mean number of repeat observations $2.5 \pm 0.32 \mathrm{SE}$, range 1-9 times each). Those repeat observations involved 28 different packs (137 different wolves, mean pack size $4.9 \pm 0.50 \mathrm{SE}$, range of pack sizes $2-11$ ) during 78 repeat events (mean number of repeat observations per pack

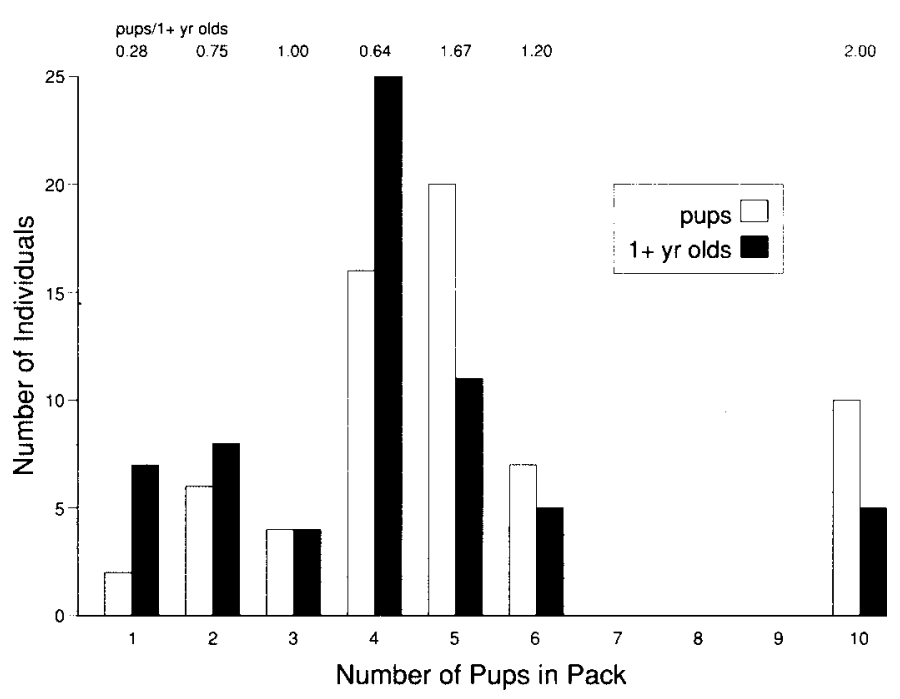

FIG. 5. Total number of wolf pups and $1+\mathrm{yr}$ old wolves in packs with pups present as a function of number of pups in the pack, Canadian Arctic Archipelago, 1967-91. 
TABLE 3. Chronological distribution of observational effort, wolf-sightings, and observational success for 24 years when field parties reported seeing wolves, Canadian Arctic Archipelago, 1967-91.

\begin{tabular}{|c|c|c|c|c|c|c|c|c|}
\hline \multirow[b]{2}{*}{ Year $^{1}$} & \multirow[b]{2}{*}{$\begin{array}{l}\text { Field-weeks } \\
\text { (n) }\end{array}$} & \multicolumn{4}{|c|}{ Wolf Observations } & \multicolumn{3}{|c|}{ Repetitive wolf-sightings } \\
\hline & & $\begin{array}{c}\text { Number of } \\
\text { observations }\end{array}$ & $\begin{array}{c}\text { Total } \\
\text { wolves }\end{array}$ & $\begin{array}{l}\text { Number } \\
\text { of Packs }\end{array}$ & $\begin{array}{l}\text { Number of } \\
\text { Singletons }\end{array}$ & $\begin{array}{c}\text { Number of } \\
\text { observations }\end{array}$ & $\begin{array}{l}\text { Number } \\
\text { of wolves }\end{array}$ & $\begin{array}{c}\text { Total } \\
\text { sightings }\end{array}$ \\
\hline 1967 & 42 & 8 & 27 & 6 & 2 & 2 & 6 & 12 \\
\hline 1968 & 21 & 6 & 10 & 2 & 4 & 0 & 0 & 0 \\
\hline 1970 & 21 & 3 & 4 & 1 & 2 & 0 & 0 & 0 \\
\hline 1971 & 32 & 8 & 13 & 1 & 7 & 0 & 0 & 0 \\
\hline 1972 & 50 & 26 & 80 & 11 & 15 & 6 & 13 & 23 \\
\hline 1973 & 56 & 19 & 77 & 12 & 7 & 0 & 0 & 0 \\
\hline 1974 & 75 & 21 & 90 & 14 & 7 & 10 & 11 & 67 \\
\hline 1975 & 40 & 5 & 10 & 1 & 4 & 2 & 1 & 2 \\
\hline 1976 & 60 & 4 & 10 & 2 & 2 & 11 & 7 & 19 \\
\hline 1977 & 97 & 5 & 19 & 3 & 2 & 16 & 8 & 55 \\
\hline 1978 & 55 & 3 & 7 & 2 & 1 & 0 & 0 & 0 \\
\hline 1979 & 58 & 3 & 13 & 1 & 2 & 1 & 1 & 1 \\
\hline 1980 & 107 & 5 & 23 & 4 & 1 & 3 & 10 & 30 \\
\hline 1981 & 111 & 3 & 3 & 0 & 3 & 1 & 1 & 1 \\
\hline 1982 & 98 & 4 & 12 & 2 & 2 & 1 & 3 & 3 \\
\hline 1983 & 81 & 2 & 10 & 2 & 0 & 0 & 0 & 0 \\
\hline 1984 & 103 & 3 & 11 & 2 & 1 & 1 & 1 & 1 \\
\hline 1985 & 113 & 9 & 18 & 4 & 5 & 5 & 8 & 12 \\
\hline 1986 & 124 & 8 & 10 & 2 & 6 & 3 & 5 & 5 \\
\hline 1987 & 161 & 12 & 43 & 9 & 3 & 6 & 14 & 20 \\
\hline 1988 & 186 & 16 & 30 & 7 & 9 & 22 & 21 & 115 \\
\hline 1989 & 180 & 26 & 84 & 16 & 10 & 5 & 9 & 10 \\
\hline 1990 & 215 & 18 & 57 & 9 & 9 & 17 & 29 & 98 \\
\hline 1991 & 53 & 17 & 27 & 5 & 12 & 27 & 19 & 41 \\
\hline
\end{tabular}

${ }^{1}$ No information was reported for 1969.

$2.8 \pm 0.48 \mathrm{SE}$, range $1-9$ times each) and 30 single wolves during 61 repeat events (mean number of repeat observations per individual $2.0 \pm 0.33 \mathrm{SE}$, range $1-5$ times each). All of the repeat observations were obtained by ground observers, with the exception of three repeat observations of the same pack of wolves during one field period while members of the field party were airborne.

Most repeat wolf observations and repetitive wolfsightings were from field activities on the QEI (Table 2). The remaining repeat wolf observations and repetitive wolf-sightings, with the exception of one of each, came from the STI. The number of wolf-sightings per unit of effort (field-weeks) increased threefold once the initial sighting was made (515 repeats vs. 167 initial), suggesting that wolves tended to remain in the vicinity of observers following initial contact, at least during the 178 fieldweeks of observations when repeat sightings were made. The amount of effort required to make an original sighting was much greater than that required for subsequent resightings. This relative preponderance of repeat sightings over the initial observation supports the assumption that the combination of all sightings (repeat + original) would have led to an unjustified inflation of the apparent yield per unit of observer effort.

\section{Temporal Considerations}

Respondents averaged 10.9 observations of wolves annually and saw a mean of 32.2 wolves $\cdot 100$ field-weeks ${ }^{-1} \cdot \mathrm{yr}^{-1}$ between 1967 and 1991 (Table 3, Fig. 6). The number of wolves reported was highly variable from year to year (Table 3 ): total number averaged $28.7 \pm 5.65 \mathrm{SE}$ (range 3-90); number of wolf packs averaged $4.9 \pm 0.93 \mathrm{SE}$ (range $0-16$ ); and single wolves averaged $4.8 \pm 0.80 \mathrm{SE}$ (range $0-15$ ). No positive relationship could be found between observer effort (the number of field-weeks per year) and the number of wolves seen annually (Pearson Correlation, $r=0.295$; $p=0.161$ ) or the mean number of wolves per pack (Pearson Correlation, $\mathrm{r}=0.081 ; p=0.080$ ).

The temporal distribution of the wolf observations (Table 3 , Fig. 6) suggests, however, that wolves were both more common and seen at greater rates during the periods 1967-75, and 1989-91 than during 1976-88. The annual mean number of wolf observations 100 field-weeks ${ }^{-1}$ exceeded the overall mean $(10.9,1967-91)$, most frequently in 1967-75, followed by 1989-91, and remained continually below the overall mean throughout 1976-88. The number of wolves seen 100 field-weeks ${ }^{-1} \cdot \mathrm{yr}^{-1}(32.2,1967-91)$ followed essentially the same pattern.

The numbers of wolf observations and wolves seen were significantly greater in $1967-75$ and $1989-91$ than in 1976-88 $\left(\chi^{2}=498.0, \mathrm{df}=2, p<0.005 ;\right.$ and $\chi^{2}=131.8, \mathrm{df}=2, p<0.005$, respectively). Wolf observations averaged 28.5 observations 100 field-weeks ${ }^{-1}$ in $1967-75,13.6$ in 1989-91, and 5.7 in 1976-88; while mean numbers of wolves seen averaged 92.3 wolves 100 field-weeks ${ }^{-1}$ in 1967-75, 37.5 in 1989-91, and 15.4 in $1976-88$.

Packs of wolves were reported for 23 of the 24 years when wolves were seen between 1967 and 1991 (Table 3). The greatest number of wolf packs was seen in 1989 (14\% of all 


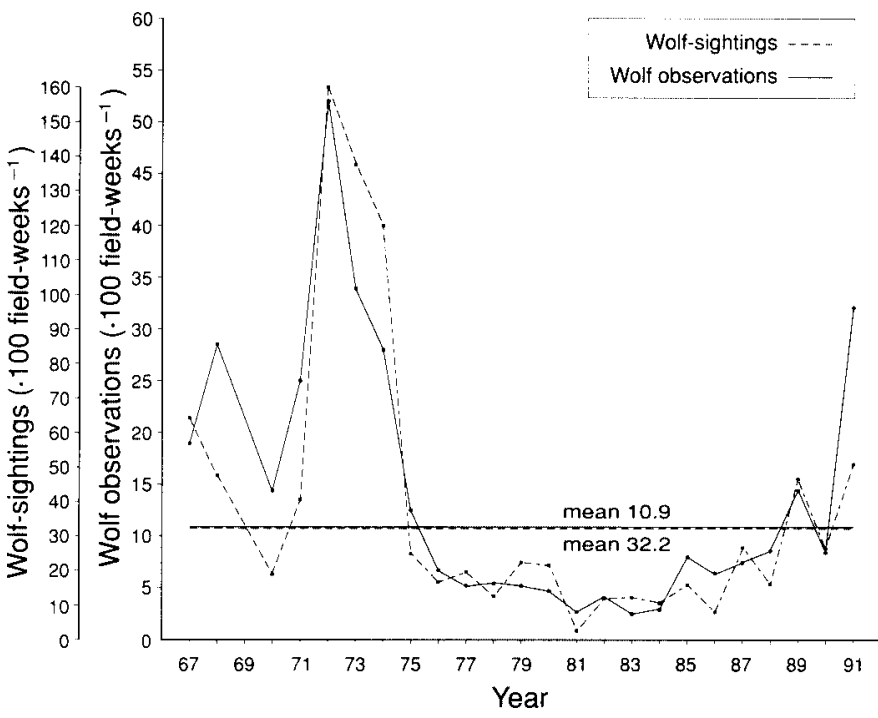

FIG. 6. Annual rates of reported wolf observations and wolf-sightings, Canadian Arctic Archipelago, 1967-91.

packs, totalling 74 wolves), followed by 1974 (12\% of all packs, totalling 83 wolves).

Respondents saw 63 wolf pups in 16 packs during 9 of the 23 years when wolf packs were seen (no packs were observed in 1981). The largest number of pups was observed in 1973 (19 pups in five observations, $30 \%$ of all pups seen); followed by 1989 , when 17 pups were observed in four sightings $(27 \%$ of all pups seen). Wolf pups were never seen in more than two consecutive years $(1973-74,1977,1979,1982-83,1987$, and 1989-90), with as many as five consecutive years (1967-72) passing without any sightings of pups being reported (the degree that the data for observation of pups, or the lack of such data, is influenced by pups' using rendezvous sites while the packs are travelling remains unknown).

Respondents reported seeing single wolves in 23 of the 24 years between 1967 and 1991 (Table 3). The largest number of different single wolves seen annually was in 1972 (13\% of all singletons), followed by 1989 (10\% of all singletons), and in 1988 (9\% of all singletons). The remaining 68\% (79 singletons) of the 116 different single wolves reported were contributed over 20 years at annual rates of ca. $1 \%$ to $8 \%(1-9$ singletons, yearly).

We cannot evaluate the observed annual variation in the reported wolf observations and wolf-sightings between 1967 and 1991 (Table 3, Fig. 6) with a high degree of confidence. That is, we have no way of truly determining how the observers involved (e.g., their training, experience and interest), location of field activities (island, area of an island, weather, time of year), and the type of field work being carried out (wide-ranging or in close to camp, and particularly low-level airborne vs. ground activities) influenced the probability of making, recording (or remembering), and reporting wolf-sightings on our questionnaire. Also, marked changes in the size or availability of the ungulate prey base over time within the different regions or major areas of the CAA where field activities were carried out would have influenced wolf numbers and, thus, the probability of seeing a wolf. It appears, however, that on average, respondents had about a one-inthree chance of making a wolf observation during any one week of field activity on the Arctic Islands where wolves were seen and reported between 1967 and 1991.

\section{Relation to Ungulate Prey}

The resultant curves (Fig. 6) are interesting in the light of known changes in numbers of Peary caribou (Rangifer tarandus pearyi) and muskoxen (Ovibos moschatus) on the QEI from 1961 to 1994 (e.g., Tener, 1963; Miller et al., 1977; Miller, 1990, 1993, unpubl. data 1984-94). Both Peary caribou and muskoxen declined drastically in the winter of 1974-75. Peary caribou numbers then continued downward during the late 1970s and into the early 1980s. A slight increase in the number of Peary caribou on the south-central QEI was first detected in the mid 1980s, with a markedly noticeable increase occurring there from the late 1980s into the early 1990s. Muskoxen were quicker to respond and began their recovery with a slow increase in the early 1980s, if not sooner. They then appeared to increase range-wide by the mid to late 1980s and into the 1990s. Thus, the reported rates of wolf observations and wolf-sightings followed the relative abundance of their major prey on the QEI-the Peary caribou and the muskox. It is impossible, however, to propose with confidence that the distributions presented in Figure 6 necessarily document a cyclic predator-prey relationship among wolves, Peary caribou, and muskoxen on the QEI from 1967 to 1991 , because too many unknowns are associated with the collection of these reported data.

Comparisons of the distributions of wolves seen and reported by questionnaire (Table 1) are only in partial agreement with the recently estimated availability of potential ungulate prey among the three regions and ten major areas of the CAA (cf. Miller, 1993). When the QEI region is considered by itself, the reported distribution of the relative number of wolves seen, the rate of wolf observations, and the rate of wolf-sightings are all in close agreement with the estimated sizes of the potential ungulate prey base within each of the five major areas (cf. Miller, 1993). Of the different wolves seen in the QEI, 90\% were reported on eastern and southwestern islands (Table 1) and $83 \%$ of the potential ungulate prey base on the QEI is estimated for those islands (Miller, 1993). When we make further intra- and inter-regional comparisons, however, the plausibility of the representative accuracy of the reported wolf observations must be questioned in relation to the relative availability of ungulate prey.

(1) Why is the reported rate of wolf observations in the QEI about threefold greater than in the BIR and STI, when the estimated ungulate prey base is tenfold and fivefold as great, respectively, in the BIR and STI as in the QEI (Miller, 1993: QEI, 20 500; BIR, 210 000; and STI, 111 300)?

(2) Why is the reported rate of wolf-sightings over threefold greater for the STI than for the BIR, when the estimated ungulate prey base is essentially twice as great in the 
BIR as in the STI (Miller, 1993: BIR, 210 000; and STI, $111300)$ ?

(3) Why is the reported rate of wolf-sightings for the eastern islands of the STI $42 \%$ greater than the rate for the western islands, when the estimated ungulate prey base is over eightfold as great on the western islands (Miller, 1993: western STI, 99000 vs. eastern STI, 12 000)?

(4) Why were no wolves seen in the northern area of the BIR, when there are fourfold as many ungulates (barrenground caribou, $R$. t. groenlandicus) estimated for the northern area of the BIR as for the entire QEI and $75 \%$ as many as in the entire STI (Miller, 1993: BIR, 84000 vs. QEI, 20 500; and BIR, 84000 vs. STI, 111 300)?

(5) Is the potential ungulate prey base so low on the southcentral islands of the STI that it does not support any wolves on a year-round basis, as the questionnaire data suggest (Miller, 1993: only 300 ungulates estimated within the entire area)?

(6) How would these results have been influenced if other researchers, who are known to have information on wolfsightings on Arctic Islands, had responded?

\section{ACKNOWLEDGEMENTS}

The study was supported by the Canadian Wildlife Service (CWS), Environment Canada, and Polar Continental Shelf Project (PCSP), Natural Resources Canada. We thank Bonni Hyrcyk, Director, PCSP, for her continued support and for having the mailing list of arctic researchers supplied to us; S.J. Barry, CWS, for statistical assistance; and J. Kennedy for drafting the maps. We offer a special thanks to all of the 107 people who took the time and made the effort to help us in our endeavour by responding to the wolf-sighting questionnaire. We are grateful to an anonymous reviewer for providing a most helpful review of the original manuscript.

\section{REFERENCES}

ANDERSON, R.M. 1943. Summary of the large wolves of Canada, with description of three new arctic races. Journal of Mammalogy 24:386-393.

- 1946. Catalogue of Canadian recent mammals. National Museum of Canada Bulletin 102 (Biological Series No. 31). Ottawa: Department of Mines and Resources Canada, Mines and Geological Branch. 238 p.

BABB, T.A., and BLISS, L.C. 1974. Susceptibility to environmental impact in the Queen Elizabeth Islands. Arctic 27:234-237.

BLISS, L.C. 1990. High Arctic ecosystems: How they develop and are maintained. In: Harington, C.R., ed. Canada's missing dimension-science and history in the Canadian Arctic Islands, Volume 1. Ottawa: Canadian Museum of Nature. 350-384.
CLARK, K.R.F. 1971. Food habits and behaviour of the tundra wolf on central Baffin Island. Ph.D. thesis, University of Toronto, Toronto, Ontario. 223 p.

DAWES, P.R., ELANDER, M., and ERICSON, M. 1986. The wolf (Canis lupus) in Greenland: A historical review and present status. Arctic 39:119-132.

EDLUND, S.A. 1990. Bioclimatic zones in the Canadian Arctic Archipelago. In: Harington C.R., ed. Canada's missing dimension-science and history in the Canadian Arctic Islands, Volume 1. Ottawa: Canadian Museum of Nature. 421-441.

EDLUND, S.A., and ALT, B.T. 1989. Regional congruence of vegetation and summer climate patterns in the Queen Elizabeth Islands, Northwest Territories, Canada. Arctic 42:3-23.

GRACE, E.S. 1976. Interactions between men and wolves at an arctic outpost on Ellesmere Island. Canadian Field-Naturalist 90:149-156.

GRAY, D.R. 1993. The use of muskox kill sites as temporary rendezvous sites by arctic wolves with pups in early winter. Arctic 46:324-330.

MANNING, T.H. 1943. Notes on the mammals of south and central west Baffin Island. Journal of Mammalogy 24:47-59.

MANNING, T.H., and MacPHERSON, A.H. 1958. The mammals of Banks Island. Arctic Institute of North America Technical Paper No. 2. 74 p.

MANNING, T.H., and MacPHERSON, A.H. 1961. A biological investigation of Prince of Wales Island, N.W.T. Transactions of the Royal Canadian Institute 33:116-239.

MILLER, F.L. 1978. Interactions between men, dogs and wolves on western Queen Elizabeth Islands, Northwest Territories, Canada. Musk-ox 22:70-72.

. 1990. Peary caribou status report. Environment Canada Report prepared for The Committee on the Status of Endangered Wildlife in Canada. Edmonton, Alberta: Canadian Wildlife Service, Western and Northern Region. 64 p.

- 1993. Status of wolves in the Canadian Arctic Archipelago. Technical Report Series No. 173. Edmonton, Alberta: Canadian Wildlife Service, Western and Northern Region. 63 p.

MILLER, F.L., RUSSELL, R.H., and GUNN, A. 1977.Distributions, movements and numbers of Peary caribou and muskoxen on western Queen Elizabeth Islands, Northwest Territories, 1972 74. Canadian Wildlife Service Report Series No. 40. 55 p.

MUNTHE, K., and HUTCHINSON, J.H. 1978. A wolf-human encounter on Ellesmere Island, Canada. Journal of Mammalogy 59:876-878.

NORTHWEST TERRITORIES DATA BOOK 1990/91. 1990. Yellowknife: Outcrop Publishing Ltd. 238 p.

PACKARD, J.M., MECH, L.D., and REAM, R.R. 1992. Weaning in an arctic wolf pack: Behavioral mechanisms. Canadian Journal of Zoology 70:1269-1275.

POCOCK, R.I. 1935. The races of Canis lupus. Proceedings of the Zoological Society of London Pt. 3:647-686.

RIEWE, R., ed. 1992. Nunavut atlas. Edmonton, Alberta: Canadian Circumpolar Institute and the Tungavik Federation of Nunavut. $259 \mathrm{p}$.

TENER, J.S. 1963. Queen Elizabeth Islands game survey, 1961. Canadian Wildlife Service Occasional Paper No. 6. 50 p. 